\section{New umbrella wins friends}

FRENCH oceanographers, geophysicists, geologists, astronomers and space scientists have clubbed together to form a new organization, INSU, the Institut National des Sciences de l'Univers, which will manage big research programmes under the financial guidance of the principal French research council for basic science, CNRS (Centre National de la Recherche Scientifique). INSU should give academic oceanographers, at least, more weight than hitherto in French science politics.

The institute has been created only after a fight from geophysicists. INSU is based on its predecessor INAG (l'Institut $\mathrm{Na}$ tional d'Astronomie et de Géophysique), where the small but effective French community of geophysicists played a strong role. INSU, to their chagrin, includes the more traditional field geologists who outnumber the geophysicists more than ten to one. Some geophysicists, who see themselves as the vanguard of French geoscience, have strongly resisted the move. The struggle continues in the universities and in the laboratories of CNRS, where geophysicists argue that geologists should relinquish more of their posts to the "new geology",

Within INSU (which will be directed by meteorologist André Berroir of the Ecole Polytechnique), realism prevails, and the talk is of new big programmes that will unite the warring tribes along the lines of the recent survey of Tibetan geology and geodynamics headed by Claude Allègre of the Institut de la Physique du Globe. Possible programmes for 1986 include a study of Caribbean tectonics and work in Latin America on the Cordillera.

Geologists themselves will also benefit from the creation in INSU of a working group on medium-scale computers for the earth sciences. Undersupplied with computers, as are many French scientists, geologists expect to need powerful minicomputers to process image data from SPOT-1, a new-generation French Earth observation satellite to be launched later this year. Both science minister Hubert Curien and Berroir, the INSU director, are in favour, even if that means using foreign machines. (Berrior masterminded the first French purchase of a non-military Cray-1.)

Oceanographers feel that the institute will strengthen academic science. In France, the field has been long dominated by the technological interests of CNEXO (recently transformed into IFREMER, the Institut Français pour l'Exploitation de la Mer, by the addition of fisheries research.) INSU should provide oceanographers with some political power, authority and even money with which to strengthen the pursuit of basic science in the face of IFREMER's largely applied bias. Hitherto, they have had to rely on a small understaffed interdisciplinary programme of the CNRS, the

UK biotechnology

\section{"PIROCEAN"' programme.}

PIROCEAN, with its FF 10 million ( $f 1$ million) budget, will now be absorbed into INSU, where it will add to the FF 35 million ( $£ 3.5$ million) brought by INAG and undoubtedly gain greater influence than it had when directly under the CNRS umbrella.

The new merger should also comfort CNEXO oceanographers whose 450 technical research staff were in danger of being swamped by the 600-700 scientists of the fisheries research organization in the earlier IFREMER merger. (That union also squeezed the research budget of both organizations, as salaries of the old fisheries organization were raised to match CNEXO's without a corresponding in- crease in total funds.)

Astronomers, meanwhile, who looked to INAG to support observatories and new telescopes, remain blissfully unconcerned. (French membership of the European Southern Observatory is paid for by the foreign ministry.) Plans are afoot for THEMIS, a high spatial resolution polarizing solar telescope for Tenerife (in collaboration with the British, Sweden, Denmark, Spain and West Germany) and for the completion of the millimetre-wave interferometer IRAM in the south of France (due to operate as an interferometer some time in 1987). But this year will be the first for which the astronomers (and geophysicists) have had to fight for large programme funds with geologists and oceanographers. The financial effects of the INSU merger will not be clear until the budget for 1986, due this autumn.

Robert Walgate

\title{
Public lab. makes private deal
}

ONE of the most unusual arrangements yet for turning public investment in research into industrial channels, Porton International, announced last week an arrangement with the British government that gives it the right of first refusal on biotechnology innovations at the Centre for Applied Microbiology and Research (CAMR), the laboratory at Porton Down in Wiltshire where British research in biological warfare was once carried out, but which was transferred to the Public Health Laboratory Service seven years ago. The same stretch of Wiltshire down remains the site of the Chemical Defence Research Establishment, operated by the Ministry of Defence.

The new arrangement is the outcome of several years of negotiation, most recently a process in which other major British companies had been asked to express an interest. Porton International already has agreements with CAMR for the exploitation of two of its proprietary developments, asparaginase (used in cancer chemotherapy) and a vaccine for herpes simplex virus (based on developments at the University of Birmingham as well as at CAMR).

In a joint statement, the company and the Public Health Laboratory Services Board said that the new arrangement will run for thirteen years from 1 April, and that the arrangement might be continued thereafter if neither party saw fit to pull out. A spokesman for Porton International said that developments not taken up by the company would remain the property of CAMR, and might be offered to other companies. But he suggested that such happenings would be few and far between.

The management of the laboratory will remain the independent responsibility of the director, Dr Peter Sutton, the Public Health Laboratory Service and ultimately the Department of Health and Social Ser- vices. But the existence of the new agreement is likely to divert the scientific interests of many members of the laboratory into directions that may be profitably exploited.

The agreement covers not merely biological materials produced by innovative methods but also new processes that may emerge (as for the manufacturer of phenylalanine and the intra-conversion of steroids). Apart from the materials already being brought to the market, there are plans for the production of frozen cell pastes (for the derivation of restriction enzymes), the production of enzymes (such as carboxypeptidases), vaccines other than herpes simplex (such as against pertussis virus) and cloned human hormones (such as human thyroid and follicle-stimulating hormones).

Under arrangements established before 1 April, Porton International is already financing the work of several members of CAMR. Nobody is as yet prepared to guess, how large a proportion of the total cost of running the laboratory will derive from royalties provided by the company on sales of proprietary products. But a spokesman for the company guessed that more than half the 250 members of staff at CAMR were working on projects with some commercial interest, but that the laboratory's basic research was also essential to the success of the new arrangement.

Porton International Ltd is for the time being a holding company, with a number of subsidiaries (such as LH Fermentation) active in fields related to biotechnology. The recent development appears to have been financed by capital contributions from a number of financial institutions, including the pensions funds of several public companies and a number of insurance companies. The chairman of Porton International is Wensley Haydon-Baillie. 